\title{
A Study of Emotional Practice in College English Teaching
}

\author{
Hong Zhou \\ Foreign Languages Department \\ Shenyang Aerospace University \\ Shenyang, China
}

\author{
Guangda Shi \\ Foreign Languages Department \\ Shenyang Aerospace University \\ Shenyang, China
}

\begin{abstract}
In recent years, many students distract from study and are addicted to phones and the internet. The improper performance in class should be revised and students' study motivation should be developed. The research believes that the teachers' emotional practice in class contributes to the sense of achievement and the study motivation of the students via the combination of the quantitative and qualitative study. It turned out that the practice of positive emotion or negative emotion in class is based on the study behaviors of the students in the class. Furthermore, the positive emotional practice of the teacher in class increased with the decrease of the students' improper study behaviors.
\end{abstract}

Keywords-emotional practice; study motivation; affective filter hypothesis; English teaching

\section{INTRODUCTION}

In recent years, many college students are addicted to mobile phones and the internet even in class. They are unrestrained and unconfident and form no good study habits. They are too shy to perform themselves before the public. They never set life goals and never satisfied with the present situation, however, they are not determined to reform the negative aspects. They never enjoy the achievement of study. Thus, the core to resolve the issue is to stimulate encourage students and tell them "They Can!" to move them internally so that students can devote themselves to study. In this sense, teachers' emotional involvement and practice are critical to improve students' motivation.

Teachers' emotional practice in class enables students to be committed to class and create a positive study atmosphere. Their passive attitude can be transformed into an active one. Besides, the teaching content ought to be practical and applicable, which can satisfy their employment demand. Students' confidence and sense of achievement can be made through teachers' emotional practice in practical teaching content. The cultivation of students' confidence and achievement can radically remove students' bad habits of hatred, blindness, laziness and ignorance of study and develop students' good study habits and independent mental activities.

\section{RESEARCH BACKGROUND}

Many scholars acknowledge that emotional factors are

This research is the fruit of Teaching Reform Project of Liaoning Province in 2018 titled "College English teaching reform exploration and practice based on curriculum ideology and politics” and also the fruit of Adult Education Teaching Reform of 2018 in Shenyang Aerospace University, titled "Research on the study motivation of adult education". significant in English teaching. Emotion affects not only the students' language acquisition [1], but also teachers' strategies, behaviors and identity recognition [2], which plays a major role in teachers professional development. Students' current distraction from studies greatly demand for teachers’ emotional involvement in class. American honored applied linguist Sarah Benesch mentioned in his book titled "Considering Emotions in Critical English Language Teaching” that to analyze English teaching from the emotional perspective is coherent with humanism, which contributes to students positive or negative study[3]. Furthermore, American linguist, Krashen also indicates the affective filter hypnosis in his language input theory. The affective filter refers to the negative affection prohibiting the acquisition and comprehension of knowledge, which is available to English teaching.

In addition, Ying, Chen from Wuhan University of Science and Technology studies the Collge English teaching Majoring in arts based on affective filter hypnosis. Xiaoying, Cao from Xian Polytechnic University analyzes how to avoid the negative affection in improving students' study atmosphere based on Krashen's affective filter hypnosis. In 2015, Haibo, Gu from Suzhou University advocates in Foreign Language Teaching and Research that the future English teaching should emphasize not only students' emotional factors but also teachers' affection in teaching and scientific research [4].

Therefore, this research focus on when, where and how to apply the positive or negative emotional stimulation in college English teaching from the teachers' angle in order to create the positive affection in students and exert a positive influence in English study.

\section{EMOTIONAL INPUT AND STUDY MOTIVATION}

American linguist Sarah Benesch reckons that scholars put more emphasis on affection research in the future foreign languages teaching, not only including the emotion involved in the students' second language acquisition but also the teachers' affection in teaching and academic research so long as to study the influence of teachers' affection on students' study effect. Sarah Benesch also indicates that the research should be expanded to the process of the emotion produced and the associated factors and how to adjust the affection. In this sense, learners are aware of how to control negative affection and how to stimulate themselves to learn. 
American linguist Krashen also mentioned affection filter hypothesis[5] in his second language acquisition theory. He argues that the emotional factors include motivation, confidence, and anxiety and so on. The affection can be adjusted in the actual teaching. The best emotional condition for learners should be the strong study motivation, full of confidence and in a happy mood, without higher or lower anxiety.

According to the above-mentioned two linguists, this research suggests that there is a close cause and effect relationship between emotional input in class and learners' study motivation. Scientific emotional input contributes to students' strong motivation. The teachers' emotional input includes positive input and negative input. In what condition, the positive or negative input should be done in class and what effects it exerts on teaching and learning, which are the focus of this research. Affection factors involved in class are shown in Fig. 1:

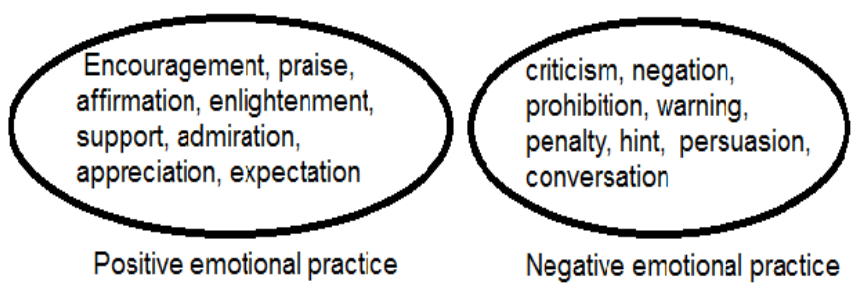

Fig. 1. The input of the emotional factors involved in class

As mentioned in the above figure, both emotions, positive and negative, should be implemented in class. Positive emotions encourage and stimulate students' active and positive study behaviors. On the contrary, the negative emotions are related to students' improper study behaviors which should be prohibited in order to make them be focused. In general, this research holds that a sensible combination between positive input and negative input in a suitable learning environment together with the psychological and character features of the students so that the best study motivation, confidence and mood can be created.

\section{Approaches to Emotional Practice in English TEACHING}

The emotional input in teaching to motivate students lies in how to stimulate students' sense of achievement, independent thinking, presenting before public, strong confidence, independent mental activity and the ability of self-learning.

\section{A. Stimulation of sense of achievement}

Nowadays, many students have no good study habits and are unable to focus on the class, thus, the teacher must take measures to involve students in the class. The best way is to put forward a proper question which is available to and interests students. For example, the teacher issues a proper and interesting question which is not too complex or too simple for the target students to answer. It is likely that most students can answer it successfully. In this way are the students satisfied and students' pursuit of knowledge are stimulated. The teacher also encourages students with encouraging words for instance "You can”, or gives them some basic concepts as clues to answer the question correctly. In the process, it is the encouragement and enlightenment which gives students a sense of achievement. They can enjoy the pleasure of success and are ready to face new challenges and answer more complex questions.

\section{B. Stimulation of independent thinking}

It is acknowledged that mobile phones are one of the necessities in our life. Many students are even addicted to the phones in class. The forcible prohibition of phones in class can make many students tiring of the class and the teacher. The key of the phone usage lies in what function the phones play in class. Thus, it is sensible for teachers to encourage phone use in class to learn a new word or encourage students to consult phones for a new concept. The positive and sensible use of phone in class can promote students independent thinking in that different students may consult different information of the new word from a different angle. Then they can share with each other the different explanation of the new word. This encouragement enables students to think independently and good self-learning habit and can convert the negative behavior to the positive one.

\section{Stimulation of presenting before the public}

It is commonly believed that many Chinese students spend several years studying English with a result to be too shy to present themselves before class. Thus, the teacher should be considerate for different identities and affections of the students and confirm every progress and good performance. Teachers spare no efforts to sing high praise for students' hard work, little progress. When the students make mistakes when presenting, teachers should guide and support them to continue the presentation in the correct way instead of discouraging or criticizing. It will take some time and patience for students to adapt to varied presentations. With confirmation, encouragement, enlightenment, praise and support, the more they practice, the more they dare to present before the public.

\section{Stimulation of confidence}

The teachers' emotional input cannot be separated from the stimulation of confidence. In psychology, unconfidence arises from the failure in study and the negation of teachers. So, a considerate word about students' study and life, praise for a little progress, and confirmation of the correct reply to a minor question can raise students' confidence. Confronting difficulties, teachers ought to enable students to admit the objectively existed realities, and encourage them to figure out methods of solution. For example, teachers often tell students "Yes, they can when they face difficulties." Teachers give an objective judgment to their merits and defects so that they can confront their mistakes in the study actively and correct them sensibly, they are not discouraged and disappointed before failure, they are not over-proud before success and achievement and they are energetic and enterprising, devoted and diligent in future study no matter success or failure. In one word, confidence means half success. 


\section{E. Stimulation of mental activity}

In class, teachers ought to stimulate students' logical thinking way by guiding them to finish a task or tackle a question, which includes the abilities of observation, comparison, analysis, synthesis, abstraction, outlining, judgment and deduction so that they express themselves accurately. For example, when explaining a very difficultly spelled word, the teacher should make students observe and analyze the base and suffix of the word in order to guide them to master the word building rules of the English words. The formation of mental activity is not easily accessible within a short period of time, which needs the enlightenment, guiding, suggesting, of the teacher in class as well as the supervision, encouragement and suitable coaching after class.

\section{F. Stimulation of self-study}

The emotional practice in class eventually aims to stimulate students the self-learning ability. In class, students' a little command of the assignment should be given praise, affirmation, encouragement and support. The teacher should give students some time to consider the question in class before the correct key is given. Another sensible strategy is to leave an independent assignment for students to accomplish after class. The teacher should suggest study methods, major thinking way and key points in accomplishing the goal. In such a process, students' sense of achievement and confidence can be built.

\section{G. The emotional practice in students' improper performance in class}

It is inevitable for students to distract from class. For instance, consulting phones for other purposes, reading other books, sleeping in class. Besides, they are absent from class, unable to finish the assignment. For these cases, teachers should converse, warn with them, even persuade them to prohibit, ban the improper behavior as a student in and after class. Generally, negative guidance should be adopted to prevent the distraction of students from class. However, the negative guidance should be adopted in a scientific manner rather than destroy students' self - respect resulting in students' tiring of study.

Generally, teachers adopt positive emotional practice together with negative emotional practice in class in that some students perform good, others perform improperly in class. The students' study behaviors and the teachers' emotional practice are shown in Fig. 2.

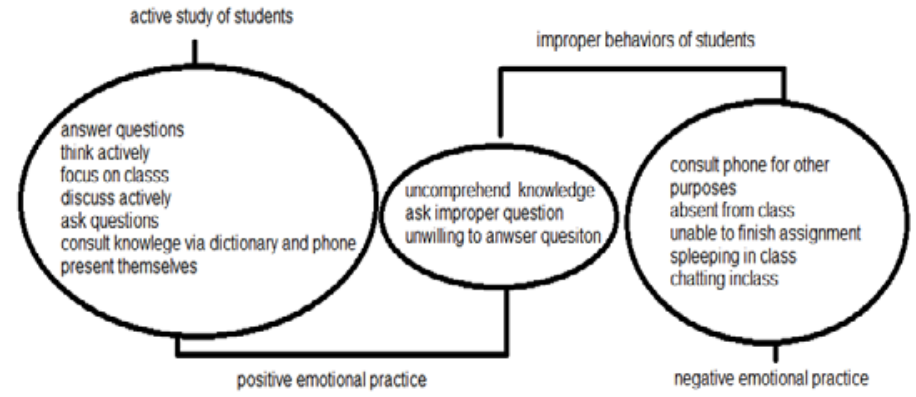

Fig. 2. Students' study behaviors and the teachers' emotional practice

As the above figure, students in the class can perform good or bad. Good study behaviors ought to be encouraged with positive emotional practice in class, while the improper study behaviors should be banned or warned in order to make them concentrate on class. However, due to students' psychological demand for praise, positive emotional practice in class dominates the whole teaching process even though the improper study behaviors exist.

\section{EFFECT OF TEACHERS’ EMOTIONAL PRACTICE ON STUDENTS’ STUDY MOTIVATION}

The emotional practice in class is aimed to motivate students to study and attain a sense of achievement from the study. After a semester's teaching, a questionnaire is conducted to learn about the students' study attitude and motivation. The results are shown in TABLE I.

TABLE I. EFFECT OF TEACHERS` EMOTIONAL PRACTICE ON STUDENTS’ STUDY MOTIVATION

\begin{tabular}{|c|c|c|c|c|c|c|c|c|}
\hline $\begin{array}{c}\text { Students } \\
\text { number }\end{array}$ & $\begin{array}{c}\text { Study } \\
\text { Interest }\end{array}$ & Confidence & $\begin{array}{c}\text { Active } \\
\text { Study }\end{array}$ & $\begin{array}{c}\text { Sleep } \\
\text { in } \\
\text { class }\end{array}$ & $\begin{array}{c}\text { Sense of } \\
\text { achievement }\end{array}$ & $\begin{array}{c}\text { Assignment } \\
\text { accomplishment }\end{array}$ & $\begin{array}{c}\text { Independent } \\
\text { thinking }\end{array}$ & $\begin{array}{c}\text { Self- } \\
\text { learning }\end{array}$ \\
\hline $\begin{array}{c}\text { Beginging } \\
\text { of the term }\end{array}$ & 25 & 22 & 18 & 5 & 15 & 28 & 20 \\
\hline $\begin{array}{c}\text { End of the } \\
\text { term }\end{array}$ & 40 & 40 & 35 & 0 & 30 & 40 & 35 \\
\hline
\end{tabular}

Questionnaires conducted in the beginning and end of the semester reveal most students' attitude and motivation development. Students' interest, confidence, attitude, sense of achievement have been improved through a semester's study. And the improper study behaviors in class have decreased greatly, especially for the behavior of sleeping in class, which diminishes totally at the end of the class. Besides, many students can think independently and learn by themselves with the help of the teacher. Almost no students are absent from class or sleep in class. Besides, the teachers' emotional input is also recorded. At the beginning of the term, the positive emotional practice in class is 10 times and the negative emotional practice is 10 times per class. In the middle of the term, the positive emotional practice in class is 15 times and the negative emotional practice is 5 times per class. And at the end of the term, almost all the emotional practice in class is positive. Therefore, the positive practice in class is in proportion to the development of the students' study motivation and interest. The teacher's positive emotional practice is increased in class attribute to the improvement of the students' study motivation and efforts. The decrease of the negative emotional practice lies in the students' increasing focus on the teacher and the class. 


\section{CONCLUSION}

This research reveals that there is a relation between students' study motivation and the teachers' emotional practice in class. Teachers adjust emotional practice according to students' study behaviors. Positive emotional practice dominates the teaching process in spite of the improper study behaviors of the students. Thus, the students' study motivation is developed proportionally with the teachers' scientific and sensible emotional practice in class.

\section{ACKNOWLEDGMENT}

I would like to appreciate the help of those who gave me a lot of inspiration to accomplish my research.
Without their suggestion, support, guiding and inspirations, I wouldn't have achieved such a fruit.

\section{REFERENCES}

[1] Arnold, J.(ed.). Affect in Language Learning[M]. New York: CUP,1999.

[2] Hargreaves, A. The emotional practice of teaching.Teaching and Teacher Education 14: 835-854, 1998.

[3] Sarah Benesch. Considering Emotions in Critical English Language Teaching. New York: Routledge[c],2012.

[4] Haibo Gu. Comment on "Considering Emotions in Critical English Language Teaching” Foreign Language Teaching and Research .2015.47 (4): 634-638

[5] Stephen D. ashen. Principles and Practice in Second Language Acquisition [M]. Oxford: Pergamum Press, 1982. 